\title{
A Compendium of Rationales and Techniques for Active Learning
}

\author{
Review of: Active Learning in College Science: The Case for Evidence-based \\ Practice, by Joel J. Mintzes and Emily M. Walter, eds.; 2020; 1001 pp.; \\ Springer (Cham, Switzerland); ISBN: 978-3-030-33599-1 (print), \$219.99; \\ 978-3-030-33600-4 (eBook), \$169.
}

Reviewed by C. Gary Reiness* Biology Emeritus, Lewis \& Clark College, Portland, OR 97219-7879
$T$ his new book seems especially timely, coming on the heels of the recent report Levers for Change: An Assessment of Progress on Changing STEM Instruction (Laursen et al., 2019). The volume is intended to persuade "skeptical but open-minded" undergraduate science, technology, engineering, and mathematics (STEM) educators to adopt one or more active-learning strategies in their teaching. In this review, I summarize the scope and style of the book, identify chapters and elements I found particularly useful or thought-provoking, report some omissions I found noteworthy, and offer some recommendations for how readers can make the most of this resource.

The book's initial section introduces constructivist learning theories, defines active learning, and provides evidence of the effectiveness of active-learning strategies for student learning. The first chapter, by Mintzes, identifies six principles derived from research on learning that should guide STEM educators, such as how prior knowledge shapes learning and how interaction with others promotes learning. These principles provide an excellent framework for any instructors who are considering revising their STEM courses. The concluding section of the book identifies the reasons that faculty or students might resist active-learning approaches and provides a wealth of tools for reducing that resistance. I found this section the most useful one, especially the concluding chapter by Silverthorn, which I recommend reading before the other practical chapters. The rest of the 61 chapters are parsed into six sections and take various approaches to the general topic of active learning. Some describe a particular active-learning strategy (use of clickers, flipped classrooms, peer instruction, etc.) and give advice about how to employ it, sometimes identifying pitfalls to avoid. Others report on discipline-based educational research (DBER) that the authors have conducted, some of which has been previously published.

A particular strength of the book is its inclusion of authors who represent a diverse array of STEM disciplines, including multiple natural sciences, engineering, and mathematics, as well as education, psychology, and economics and centers for teaching and learning. This provides perspectives that are not typically apparent in educational literature from a single discipline. I found it interesting that authors from different disciplines support essentially the same claims but do so by drawing on disparate references. This suggests that STEM education researchers and reformers tend to work in disciplinary silos and, in many cases, are not aware of similar work being conducted in other disciplines. This book therefore makes a valuable contribution to breaking down these silos. It serves as a broad introduction to DBER in a variety of fields up through roughly the end of 2018. Although much of the material in this volume can be obtained, with effort, by searching the published literature, the inclusion of a wide selection in a single volume makes it a useful starting point to learn the status of educational reform in a variety of STEM fields.

While the editors (and most authors) embrace the position that active learning is preferable to more traditional STEM education methods (such as lecturing and "cookbook" laboratory exercises), there is some diversity of opinion. For example, in

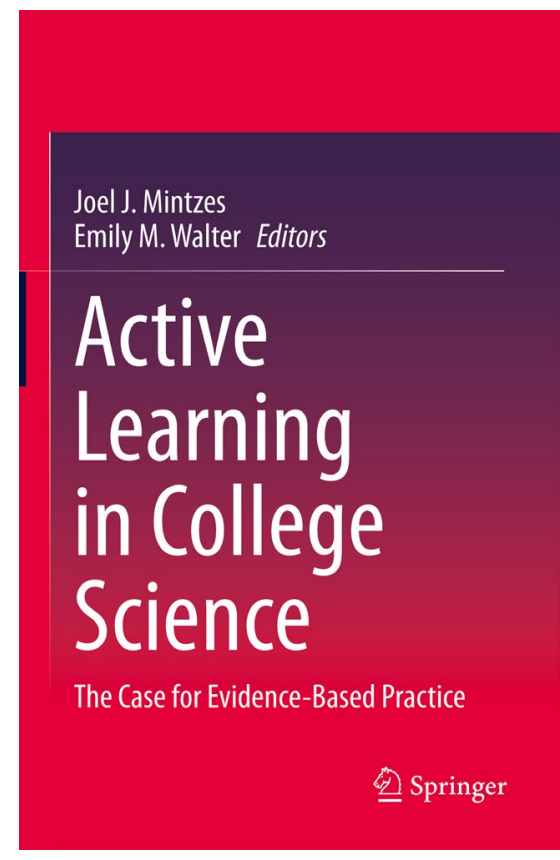

CBE Life Sci Educ December 1, 2020 19:fe6 DOI:10.1187/cbe.20-08-0177

*Address correspondence to: C. Gary Reiness (reiness@lclark.edu)

(C) 2020 C. G. Reiness. CBE-Life Sciences Education () 2020 The American Society for Cell Biology. This article is distributed by The American Society for Cell Biology under license from the author(s). It is available to the public under an Attribution-Noncommercial-Share Alike 3.0 Unported Creative Commons License (http://creativecommons.org/licenses/ by-nc-sa/3.0).

"ASCB®" and "The American Society for Cell Biology ${ }^{\circledR}$ " are registered trademarks of The American Society for Cell Biology. 
the chapter "Student-Generated Instructional Materials," Coppola and Pontrello provide an instructive overview of the stated topic, but also devote much of the chapter to critiquing several approaches to active learning and defending lecturing and other forms of instructor-centered teaching. This perspective appears to fly in the face of Carl Wieman's (2014) comment that "most STEM courses are still taught by lectures-the pedagogical equivalent of bloodletting," which the editors quote in the preface. In fact, Coppola and Pontrello explicitly reject Wieman's comparison and take exception to some of the other conclusions of Wieman and Eric Mazur. They dislike the term "evidence-based practices," which is in the book's title, and caution against overreliance on concept inventories to assess student learning. They assert that most DBER is designed to verify that an active-learning approach is preferable to lecturing rather than to gather data about who does or does not benefit from these approaches and under what circumstances. They object to the assumptions that underpin "scientific teaching" (Handelsman et al., 2007), grounding their position in an extensive review of literature, including many sources not commonly found in DBER publications. This chapter is provocative in the best sense of motivating one to reconsider one's assumptions about educational practices. Because most of the other authors in this volume embrace viewpoints and strategies that Coppola and Pontrello criticize, I found myself wishing that the volume had contained a more direct dialogue among authors who hold different positions about the value of active learning.

The chapters also vary widely in their intent, with some endeavoring to reach a wide range of readers and others framed with narrower focus, such as applying a technique to a single STEM discipline. For example, in "Clickers in the Biology Classroom," Smith and Knight provide extensive advice about effective practices in employing clickers that will be useful for any STEM educator. Conversely, the chapter "Gamification in General Chemistry" describes how using a computer game that teaches basic chemical concepts (stoichiometry, balancing equations) affects student learning; it will mostly interest chemists. In the chapters that describe studies of the impact of introducing some active-learning strategy on student outcomes, some provide extensive context, essentially a literature review, for their work, along with describing the results of an intervention (such as the chapter on "Investigative Science Learning Environment: Learn Physics by Practicing Science"). Others focus more narrowly on the results of a single study. I found the most valuable chapters to be those that provide a broad overview of a topic or identify general principles that should guide implementation of a particular strategy whatever the reader's discipline or institution type; these constitute about 25 of the 61 chapters.

As is typical for a multiauthor volume, there is considerable variation in the quality of the contributions; the writing ranges from excellent and engaging to serviceable. There is also great deal of redundancy in the literature discussed as well as some surprising omissions. Although the volume provides an extensive overview of a large number of active-learning strategies, it is not comprehensive. For example, the peer instruction method developed by Eric Mazur (1997) and colleagues at Harvard is described in several chapters, and an entire chapter by Varma-Nelson and Cracolice is devoted to peer-led team learning. The strategy of team-based learning (Michaelson et al.,
2008) is extensively and clearly detailed in a chapter by Leupen, who provides guides and resources (books, annual training workshops) for anyone interested in adopting that approach. On the other hand, the widely used process-oriented guided inquiry learning strategy is mentioned only twice and not described in detail anywhere. Resources such as BioQUEST and the Summer Institutes on Scientific Teaching are not mentioned at all. Several authors note the importance of helping students develop their metacognitive skills, yet there is no explicit discussion of how to do that in any chapter, nor any mention of a well-known resource for teaching metacognition (McGuire and McGuire, 2015).

The book lacks an index, and the chapter titles do not always reflect chapter content. Thus, readers may have to invest some effort to locate particular topics of interest to them and should peruse chapters that, at first glance, may seem less relevant to them. For instance, the chapter by Coppola and Pontrello noted earlier is at least as much about challenging the assumptions of some advocates for active learning as it is about the stated title. A chapter by Linton entitled "Peer Interaction in Active Learning Biology" is noteworthy for providing detailed information about how to construct collaborative student work groups effectively (appropriate group size, demographic composition, etc.) that will be useful to any STEM educator interested in collaborative learning, not only biologists.

Beyond these quibbles, there are two noteworthy omissions that, in my view, diminish the value of the book. The first is an insufficient attention to diversity, equity, and inclusion. Only two chapters are devoted explicitly to diversity and universal design for inclusion (chapters 54 by Ballen and 59 by Google and colleagues). A few other chapters discuss the impact of active-learning pedagogies on diversity in STEM, but the issue is not addressed in most chapters and the theme of equity and inclusion is not woven throughout the volume. It is well documented that students whom David Asai terms "science PEERs" (persons excluded because of their ethnicity or race)-particularly African-American, Native-American, and Latinx students-leave science majors at much higher rates than other students (Asai, 2020). Although there are multiple citations to the work of Freeman et al. (2014) and Eddy and Hogan (2014) documenting the effectiveness of active learning for reducing these disparities, it was surprising that more chapters did not address to what extent and in what circumstances particular strategies can promote equity and inclusion.

A second shortcoming is that many of the strategies described in the volume are expensive to implement, in time or other resources, and insufficient attention is paid to how they can be adopted by overextended faculty at institutions with few resources. The editors note in their preface that the book is intended for "thousands of dedicated faculty and graduate students who teach undergraduate science at community and technical colleges, 4-year liberal arts institutions, comprehensive regional campuses, and flagship research universities." However, it seemed to me that the 127 authors, who are predominantly affiliated with doctoral or comprehensive master's-granting universities, were primarily addressing an audience of STEM educators at institutions like their own. Doctoral and master's institutions constitute about a quarter of all U.S. institutions of higher education and enroll just over half the 
undergraduate students (Center for Postsecondary Research, 2018). The remaining three-fourths of institutions, enrolling nearly $50 \%$ of undergraduates, are baccalaureate colleges, associate's (2-year) colleges, special focus 2- and 4-year colleges (such as art schools), and tribal colleges. In particular, community colleges enroll between a third to more than $40 \%$ of undergraduates, including up to half of Latinx and African-American undergraduates; about $70 \%$ of community college students come from families with incomes under $\$ 50,000$ (in 2015-16) (Community College Research Center, n.d.). Despite enrolling a disproportionate fraction of the undergraduate students from low-income families and underserved racial and ethnic groups, community colleges are often overlooked in education research (Schinske et al., 2017), and community college faculty do not seem to be the intended audience for this volume.

As I was reading chapters that recommended involving graduate teaching assistants or undergraduate learning assistants, drawing on teaching and learning centers, acquiring internal or external grant support to launch a reform initiative, or remodeling classrooms to include the latest technology, I could not help but wish they had also offered advice to instructors who had access to none of those resources about how they also could implement active-learning strategies. Students at community colleges or poorly resourced 4-year colleges deserve the same inclusive, efficacious STEM education as those at larger and richer institutions, especially if we are serious about improving the diversity of the scientific community. It is possible for a single faculty member or small group of colleagues to adopt active-learning strategies economically, and I wish there had been more attention given to this. To be fair, some chapters identify tools or strategies that need not cost much in money or time. An excellent chapter by Kiste on implementing a "studio" approach to general chemistry was noteworthy, because it provided very explicit information about how his university changed from lecture to studio-style pedagogy and improved student learning. He also addressed how faculty and staff workloads and the need for other resources were affected (not much). However, most chapters seemed to be written with the assumption that instructors who wished to adopt particular strategy would have access to equivalent resources. I doubt this was true even before budgetary restrictions caused by the Covid-19 pandemic were imposed, and it is certainly not true now. In short, I had hoped to see a more direct consideration of how instructors can do right by students even when resources are limited.

Despite these concerns, this book is sufficiently worthwhile to justify its addition to a college or university library or teaching and learning center (assuming an institution has one), although I do not think it is suitable for a personal library. I recommend getting the ebook rather than the print edition, because it is less expensive and the Find function mitigates the absence of an index. I do not recommend reading this book of 61 chapters and more than 1000 pages from beginning to end.
Instead, I suggest reading the first five chapters carefully for their focus on why active learning matters and then reading the last section (Chapters 54-61, except 57) for its focus on the principles for effectively implementing active-learning strategies. Doing this should persuade the "skeptical but open-minded readers" to employ active-learning pedagogies or nudge those already favorably inclined to add other tools to their teaching. The remaining chapters then offer many examples of effective strategies that are applicable to most any STEM discipline. Readers can home in on those that seem most relevant to their personal or institutional situation while reserving the others for perusal if time allows. In producing this volume, Mintzes and Walters have provided a helpful resource for STEM educators.

\section{ACKNOWLEDGMENTS}

I thank Paulette Bierzychudek and Jenny McFarland for their insightful comments on earlier drafts of this review.

\section{REFERENCES}

Asai, D. J. (2020). Race matters. Cell, 181, 754-757. https://doi.org/10.1016/j. cell.2020.03.044

Center for Postsecondary Research. (2018). Carnegie Classifications update. Bloomington: Indiana University School of Education. Retrieved June 1 2020, from https://carnegieclassifications.iu.edu/downloads/CCIHE2018 -FactsFigures.pdf

Community College Research Center. (n.d.). Community college FAQs Retrieved June 1, 2020, from https://ccrc.tc.columbia.edu/Community -College-FAQs.html.

Eddy, S. L., \& Hogan, K. A. (2014). Getting under the hood: How and for whom does increasing course structure work? CBE-Life Sciences Education, 13, 453-468. https://doi.org/10.1187/cbe.14-03-0050

Freeman, S., Eddy, S. L., McDonough, M., Smith, M. K., Okoroafor, N., Jordt H., \& Wenderoth, P. (2014). Active learning increases student performance in science, engineering, and mathematics. Proceedings of the National Academy of Sciences USA, 111(23), 8410-8415. https://doi .org/10.1073/pnas.1319030111

Handelsman, J., Miller, S., \& Pfund, C. (2007). Scientific teaching. New York: Freeman.

Laursen, S., Andrews, T., Stains, M., Finelli, C. J., Borrego, M., McConnell, D., ... \& Foote, K. (2019). Levers for change: An assessment of progress on changing STEM instruction. Washington, DC: American Association for the Advancement of Science.

Mazur, E. (1997). Peer instruction: A user's manual. Upper Saddle River, NJ Prentice Hall.

McGuire, S., \& McGuire, S. Y. (2015). Teach students how to learn: Strategies you can incorporate in any course to improve student metacognition, study skills, and motivation. Sterling, VA: Stylus.

Michaelson, L., Parmelee, D., McMahon, K., \& Levine, R. (Eds.) (2008). Teambased learning for health professions education. Sterling, VA: Stylus.

Schinske, J. N., Balke, V. L., Bangera, M. G., Bonney, D. M., Brownell, S. E., Carter, R. S., ... \& Corwin, L. A. (2017). Broadening participation in biology education research: Engaging community college students and faculty. CBE-Life Sciences Education, 16(2), mr1. https://doi.org/10.1187/ cbe.16-10-0289

Wieman, C. (2014). Large-scale comparison of science teaching methods sends clear message. Proceedings of the National Academy of Sciences USA, 111(23), 8319-8320. https://doi.org/10.1073/pnas.1407304111 